\title{
ALGINATES AND SIMILAR EXOPOLYSACCHARIDES IN BIOMEDICAL APPLICATION AND PHARMACY: CONTROLED DELIVERY OF DRUGS
}

\author{
Dragana Marković ${ }^{1}$, Aleksandra Zarubica ${ }^{1}$, Nikola Stojković ${ }^{1}$, Marija Vasić1, \\ Milorad Cakić ${ }^{2}$, Goran Nikolić ${ }^{*}$ \\ (REVIEW PAPER) \\ UDC 577.114:615.01 \\ 1 Department of Chemistry, Faculty of Science and Mathematics, University of Niš, Niš, Serbia
2 Faculty of Technology, University of Niš, Leskovac, Serbia
}

Due to its biocompatibility, biodegradability, hydrophility, technological properties and vast availability, polysaccharides are widely used as natural non-toxic polymers in different branches of industry (food, cosmetic, textile, construction industries). Exopolysaccharides (as dextran, pullulan) have recently taken up a significant position in pharmaceutical industry. Alginate has an irreplaceable role in biomedicine, since its hydrogel form is successfully applied for immobilization of a wide range of enzymes, therapeutics, biochemical agents and different kinds of microorganisms and cells (herbal, animal or human). Alginate microspheres and microcapsules are used for controlled release of biologically active molecules, as well as cell carriers in tissue engineering. Special benefits are brought by the simplicity of configuration of alginate hydrogel, including the possibility of the controlled production of micro- and nanoparticles. Taking into account a very important role of alginates in the form of hydrogel in biomedicine, in this paper a specific attention is paid on the preparation and application of alginate matrices, microspheres and microcapsules that may have essential and unexchangeable usage/application. This paper therefore displays various possibilities of use of polysaccharide matrices for biomolecules, polysaccharide as excipients of pharmaceutical products for oral or local application, and provides a review of the examples of innovative applications.
Keywords: polysaccharide, alginate, microcapsules, biomedicine, pharmacy.

\section{Introduction}

Polysaccharides are natural, non-toxic, biocompatible substances which have specific physical and chemical properties which make them suitable for different kinds of pharmaceutical applications. They come from renewable sources, and they are widespread within living organisms, often with economic advantages over synthetic polymers [1]. Apart from a large number of macromolecules, polysaccharides can be successfully used for forming delivery systems of medicines in the form of hydrogels [2].

Polysaccharide hydrogels are very similar to living tissues, and they are therefore widely applicable in biomedicine [3]. Numerous studies in this area have brought large contributions to our understanding of polysaccharide hydrogel networks today; a wide spectrum of systems of these specific classes of materials is suggested [2]. Apart from their vast diversity in the modified systems of a medical drug delivery, special progress was made in terms of the use of hydrogel as a matrix for the encapsulation of living cells, as a biological material in tissue engineering and for controlled release of protein [3]. Physically networked gels are of high significance, considering the fact that gelation can take place in mild conditions and in the absence of the organic solvent. For the purpose of the preparation of different kinds of hydrogel, especially as systems of delivering various medical substances in the body, different types of polysaccharides were tested: alginate, dextran, pullulan, carrageenan, guar gum, hyaluronic acid, scleroglucan, xanthan, xyloglucan, pectin, chitosan, etc. [3].

The aim of this study is to provide a modern review of examples of polysaccharide innovative applications in biomedicine and their significant position in pharmaceutical industry. Therefore, this paper displays various possibilities of use of polysaccharides matrices for biomolecules, and different polysaccharide forms as excipients of pharmaceutical products for oral or local application. For this study, a variety of scientific databases and services (medline, pubmed, and scopus) were used according to defined keywords (polysaccharide, dextran, pullulan, alginate, hydrogel, complexes, nanoparticles, matrices, microspheres, microcapsules, biomedicine, and pharmacy). The study included relevant findings in the period of their occurrence and development (before the year 2000) and modern applications (after the year 2000).

\footnotetext{
*Author address: Goran S. Nikolić, University of Niš, Faculty of Technology, Bulevar oslobodjenja 124, 16000 Leskovac, Serbia

E-mail: goranchem_yu@yahoo.com

The manuscript received: March, 24, 2016.

Paper accepted: June, 07, 2016.
} 


\section{Polysaccharide complexes}

Metal polysaccharide complexes

The investigations of bioactive metal polysaccharide complexes are very interesting in medicine and pharmaceutical industry, with the aspects on therapy of different states of anemia or metabolism disorder [1]. On the other hand, polysaccharides and their derivatives, as the most abundant class of biomolecules, are known to have a large variety of biological functions [4]. Through the interaction between these polyfunctional molecules and metal ions in living organisms, the modification of the biological function of both counterparts may be expected [5]. One of the known roles of the polysaccharide complexes is the transport of metal ions through cell membranes.

The polysaccharide type compounds as ligands have received considerable interest [6]. For example, the commercial iron and copper preparations based on dextran and their derivatives are used for such purpose in both human and veterinary medicine $[6,7]$. Bioligands or synthetic ligands are mainly natural chemical compounds of a macromolecular type. In this group of products chemical compounds of pullulan [8,9], dextran [10-12], and inulin [13] with cations of the different biometals ( $\mathrm{Fe}, \mathrm{Cu}, \mathrm{Co}$ and $\mathrm{Zn}$ ) are of special importance.

It is well-known that raw microbiological exopolysaccharides dextran and pullulan are glucose polymers with a large molar mass (from a few millions $\mathrm{g} / \mathrm{mol}$ ), with their own toxic and antigen characteristics, so that they are not of pharmaceutical importance. For commercial reasons, raw polysaccharides were depolymerized to the products with adequate molar masses, with the aim of getting fractions with narrow molar mass distribution $[12,14]$. The procedures for the complex formation of biometals with polysaccharides are described in scientific and patent literature [15]. Polysaccharides and their derivatives with reduced and oxidized groups form metal ion complexes of various composition and stability (Fig. 1).

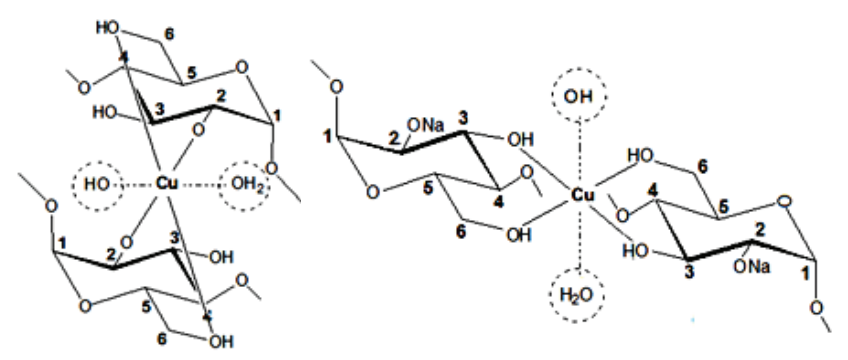

Figure 1. Structural models of bioactive copper complexes with dextran (A) and pullulan (B) in antihypocupremical formulations [6]

In the field of biocoordination chemistry, a lot of investigations are based on the synthesis and characterizations of different metal complexes of ligands they present in biological systems or synthetic ligands, which will serve like the model-molecules for complex biomolecular structures (Fig. 2).

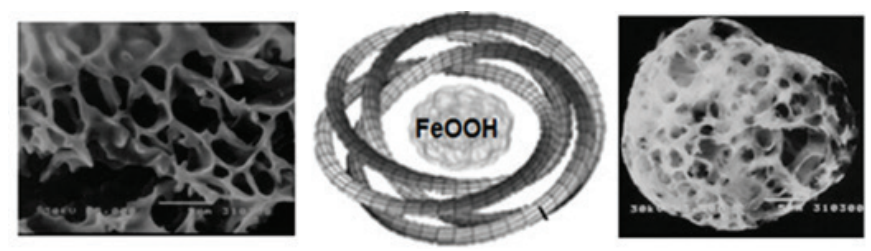

Figure 2. Micrograph of polysaccharide matrix and a structural model of encapsulation of bioactive iron $(\mathrm{FeOOH})$ in pullulan microsphere to antianemic iron-pullulan formulations [8]

\section{Polysaccharide microcapsules}

A glucose polysaccharide has an important role in the development of deliverance systems for some medicines and proteins, apart from being widely used in pharmacy, for example dextran as plasma replacement. Thus, the dextran gel network was examined as a potential system for the delivery of invertase, which had been chosen as a model of protein and embedded into the hydrogel. A derivate, glycidyl methacrylate dextran, was used as the carrier of some proteins (lysozyme, albumin, BSA, immunoglobulin G, IgG) [16]. Sulphopropyl dextran microspheres fulfilled with watery soluble medicines may be introduced in cellulose acetate butyrate based microcapsules [3]. Microspheres of inulin acetate and inulin acetate succinate with drug (chlorhexidine and chymotripsin) were prepared by the solvent precipitation method [17]. The morphology and photomicrograph of some microspheres loaded with drugs, determined by scanning electron microscope, are presented in Fig. 3.

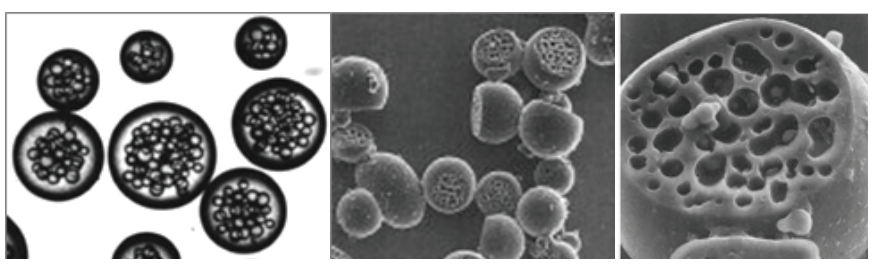

Figure 3. Morphology of polysaccharide microcapsules with medical substances $[3,17]$

\section{Inclusion complexes}

Inclusion complexes with cyclodextrins and their derivatives are increasingly used in order to improve the physical and chemical characteristics (solubility, evaporation, unpleasant smell, stability increase, activity etc.) of pharmaco-logically active substances (Fig. 4).

There is a number of scientific works showing the solubility and stability increase within many drugs, such as: atenolol, nifedipine, amlodipine, allicin, usnic acid [18]. In order to improve the solubility and photostability of sulfanilamide, a complex of sulfanilamide with $\beta$-cyclodextrin, incorporated into the liposomes was prepared [19]. Several other polysaccharides have been studied and proposed for the formulation of modified release dosage forms and devices, so to draw up a complete list would be a very difficult task. Taking into account a very important role of alginates in the form of hydrogel in biomedicine, in this work a specific attention is paid on the 
preparation and application of alginate matrices, microspheres and microcapsules that may have essential and unexchangeable usage/application.
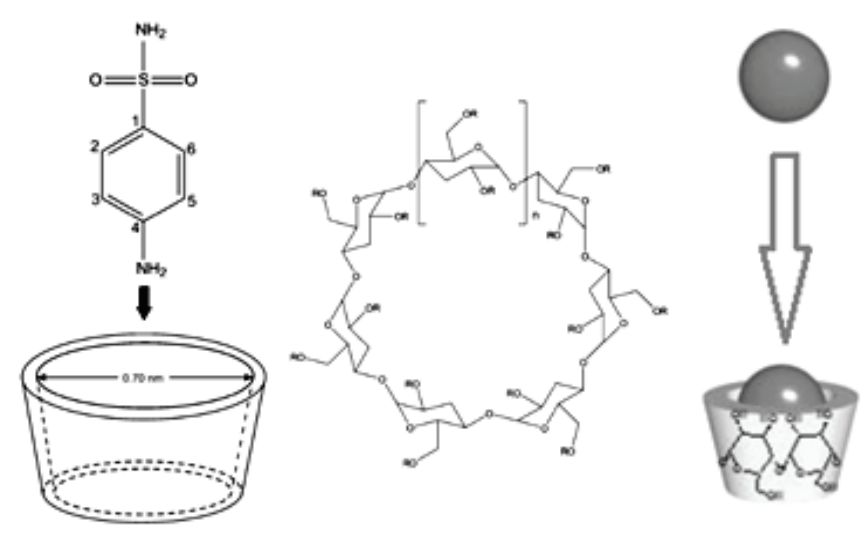

Figure 4. Schematic presentation of sulfanilamide inclusion in the cyclodextrin cavity [19]

\section{Alginate forms}

Alginates are among the most frequently studied and applied polymers in the areas of tissue engineering and controlled release of medical substances in the organism. These polysaccharides are widespread throughout nature. They can be found as structural components of cell walls in some brown sea algae (up to $40 \%$ of dry mass), or as capsulated polysaccharides in certain earth bacteria [20]. The most commonly known species of brown algae used for the extraction of alginic acid, i.e. its salts (alginates), are Ascophyllum nodosum, Laminaria hyperboreanand Macrocystis pyrifera. The bacterial alginates are isolated from Azotobacter vinelandii, as well as some species of Pseudomonas. Alginates also exist as salt mixtures of different cations $\left(\mathrm{Mg}^{2+}, \mathrm{Sr}^{2+}, \mathrm{Ba}^{2+}\right.$ i $\left.\mathrm{Na}^{+}\right)$ present in salt sea water [21].

\section{Importance of structure}

Alginates are a monovalent form of alginic acid. As polysaccharide block copolymers [22], they are composed of monomers, $\beta$-D-mannuronic acid (M-block) and $\alpha$-L-guluronic acid (G-block) and a region in which $\mathrm{M}$ and $\mathrm{G}$ units rotate, connected by $1-4$ bonds (Fig. 5). The length of the M-block and G-block and sequential distribution along the polymer chain varies depending on the source of the alginate. The composition and extent of sequences and the molecular weight determine physical properties of alginates. By varying the ratio of $G$ and $M$ units, it is possible to influence the properties of the ionic connected alginates based hydrogel. This gentle property has led to their wide use as cell transplantation vehicles to grow new tissues and as wound dressings. Moreover, alginate as an anionic polymer with carboxyl end groups is a good mucoadhesive agent [20]. However, alginate hydrogels used in these applications have uncontrollable degradation kinetics and gels dissolve in an uncontrollable manner following the loss of divalentcations releasing high and low molecular weight alginate units. Attempts have been made to covalently crosslink sodium alginate with gelatin, sodium tetraborate or with albumin [23].

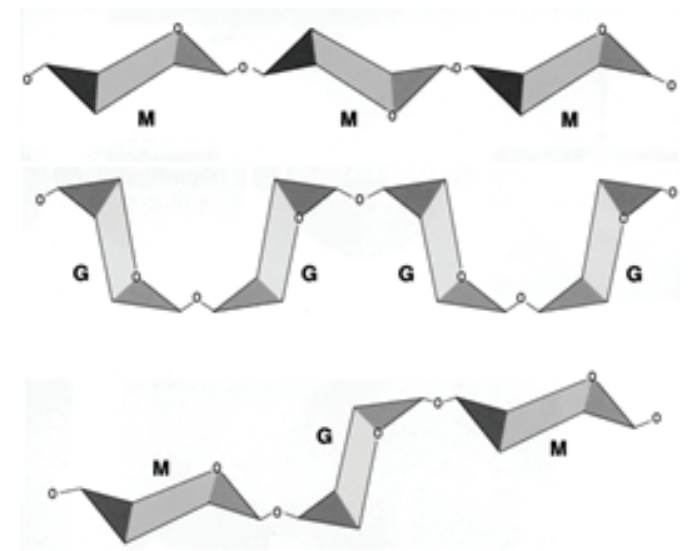

Figure 5. The structure of a polysaccharide alginate block copolymer with $\mathrm{G}$ and $\mathrm{M}$ units

In water solution, in the presence of a divalent cation (e.g. $\mathrm{Ca}^{2+}$ ) or a trivalent cation, alginates are exposed to ionotropic gelation [24]. Namely, in block copolymers, there are hydrogen bonds between the COO group of mannuronate and $\mathrm{OH}^{-}$groups of the guluronate part. This hole has dimensions that are ideal for the cooperative binding of calcium ions. The $\mathrm{Ca}^{2+}$ ions create the intermolecular structure (so called "egg box" configuration) in the connection regions (1-3 nm) that is very similar to the quaternary biopolymers structure (Fig. 6).

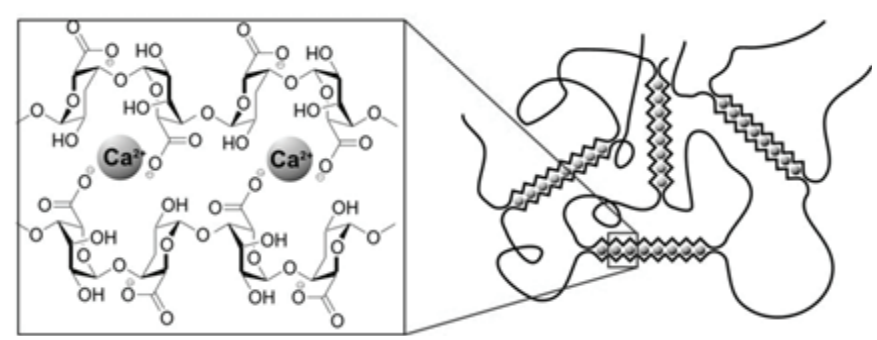

Figure 6. The ordered three-dimensional structure of ionotropic gel with an "egg-box" configuration of alginate and calcium ions

\section{Important properties}

Solutions of Na-alginates with a high content of $\alpha-L-$ guluronic acid (> 75\%) are very viscous. Microorganisms attack Na-alginate less frequently than other carbohydrates. Alginates with a high content of $\alpha$-D-mannuronic acid have flexible chains and display lower levels of viscosity (by 20\%) at the same shearing speed. The absence/loss of viscosity is a result of depolymerization of polymers chains. When solutions of alginates come in contact, they will contribute to the binding of guluronic acid with polycations to form a gel [25]. A space inside the polymer network of alginates hydrogel would enable the introduction of cells and molecules of medicinal substances [26]. Grafting of synthetic monomers into algi- 
nates is developed to eliminate undesirable features of alginates.

The structure of the gel, as the effect of the multivalent cation, is more elastic in the case of materials rich in mannuronic components and they also display a higher degree of swelling than the materials rich in a guluronic component (swelling rate 30\% higher). However, the resulting gel structure, even in the cases of materials rich in a mannuronic component, has shown very intensive properties of plasticity. An efficient way of testing the validity of these materials for their application in biomedicine is to test the reaction of the materials to volume deformity caused by the growth of immobilized cells. Typically, the shift in the hydrogel volume during the cell growth process causes the volume expansion of the hydrogel due to electrostatic repellency interactions caused by the destruction of its structure.

The solubility of salts of the alginic acid is dependent on $\mathrm{pH}$ and a type of the existing cations. Depending on the conditions, alginates form two types of gels: the acidic and the ionotropic gel. In the case of a slight decrease of $\mathrm{pH}$ value of the solution below the $\mathrm{pKa}$ of guluronic acid ( $\mathrm{pKa}=3.65)$ and mannuronic acid $(\mathrm{pKa}=3.38)$, alginate salts turn into a gel state, forming the so-called acidic gel, stabilized by intermolecular hydrogen bonds The central elements of the gel are polyguluronic segments, while the forming of the gel is stimulated by the alternately arranged polymannuronic segments [27]. The ionotropic gel is a result of the interaction of multivalent cations $\left(\mathrm{Ca}^{2+}, \mathrm{Ba}^{2+}, \mathrm{Sr}^{2+}, \mathrm{Al}^{3+}\right)$ and polymer chains. The affinity of alginates drops in the following order: $\mathrm{Pb}^{2+}>$ $\mathrm{Cu}^{2+}>\mathrm{Ba}^{2+}>\mathrm{Sr}^{2+}>\mathrm{Cd}^{2+}>\mathrm{Ca}^{2+}>\mathrm{Zn}^{2+}>\mathrm{Co}^{2+}>\mathrm{Ni}^{2+}$. The exceptions are $\mathrm{Mg}^{2+}$ and monovalent ions, which form a viscous colloid solution [28]. Ionotropic gelation implies the exchange of $\mathrm{Na}^{+}$ions with the guluronic acid salts; e.g. $\mathrm{Ca}^{2+}$ ions bind parts of units of guluronic acid and cause their conversion to create ordered tridimensional structure ("egg box"), which is additionally stabilized with hydrogen bonds. Interactions are not only electrostatic but of coordinative nature with multivalent cations as helat ligands.

Unlike the acidic gel, in this case the forming of the gel is influenced only by the polyguluronic sections which, because of the spatial arrangement of oxygen atoms in $\mathrm{OH}^{-}$i COO- groups, have a high affinity towards polyvalent cations. A numerous studies have showed that a chemical structure, molecules dimensions and kinetics of the gel forming have an important influence on their functional properties such as porosity, viscosity, stability, biodegradability, immunologic features and biocompability.

\section{Alginate implementations}

Biocompatibility

Alginates have been included by the FDA in the group of compounds considered generally safe for oral application. Alginates are non-toxic and biodegradable when applied orally, and they cause no immunoreactions, which is not the case when they are applied intravenously [29].
The intravenous application or the application in the form of implants could cause immunoreactions, probably due to toxic contaminates of commercial alginates.

\section{Bioadhesivity}

Mucoadhesive substances have a property of remaining longer at the place of application. Alginates have mucoadhesive characteristics, contributing to the transport of medical substances to mucosal tissues [30]. The results of other authors have reported that these polymers may be good mucoadhesive agents where a higher charge density would enable better adhesion [31]. Polyanionic polymers are more efficient as bioadhesives than polycationic and non-ionic polymers. Therefore, alginates are very good mucoadhesive agents as anionic polymers with carboxyl groups. Alginates have greater mucoadhesive strength than polymers such as polystyrene, chitosan, carboxymethyl cellulose and poly(lactic acid) [32]. The bioavailability and efficacy of a drug is higher as a result of better adhesivity of alginate particles onto the mucosal tissues, while the passage time for proteins is longer and the drug is localized on the absorptive surface.

\section{$\mathrm{pH}$ sensitivity}

The release of macromolecules from alginate pearls at low $\mathrm{pH}$ values of the solution is significantly lowered, which is certainly an advantage in the development of drugs for oral application [33]. Alginates shrink at lower $\mathrm{pH}$ values (the mid-part of the stomach), and thus the encapsulated drugs cannot be released [34]. In gastric fluid, the hydrated sodium alginate turns into a porous, insoluble, so-called alginate-acid capsule. When it goes into the intestinal tract (higher $\mathrm{pH}$ ), this layer is converted into a soluble viscous layer. Thus, the $\mathrm{pH}$ dependent behavior of alginates can be exploited in order to adjust the release profile of a drug. However, the quick dissolution of the alginate matrix at higher $\mathrm{pH}$ values could lead to the sudden release of the protein drug, followed by its denaturation by means of a proteolytic enzyme. Therefore, significant modifications of physical and chemical properties of alginates are necessary for the prolonged controlled release of protein drugs.

\section{Alginates as protein traps}

Proteins trapped in the alginate beads/pearls could be prepared by extruding the sodium alginate solution that contains a desired protein, as adroplet, into bivalent cross-linked solution of $\mathrm{Ca}^{2+}, \mathrm{Sr}^{2+}$ or $\mathrm{Ba}^{2+}$. The biological activity of drugs may be retained in the encapsulation process of cross-linked calcium alginate (Fig. 7). Although the micro-environment of an alginate grain can be relatively resistant to protein drugs and cells, proteins with a positively charged protein can be competitors to $\mathrm{Ca}^{2+}$ ions for free carboxylic alginate groups. This is a characteristic of small drug molecules [35]. Alginate as a pearl or microcapsule can be used to capture proteins such as melatonin [36], heparin [37], hemoglobin [38] 
and vaccine [39]. Coated pearls and microspheres function better in oral application.

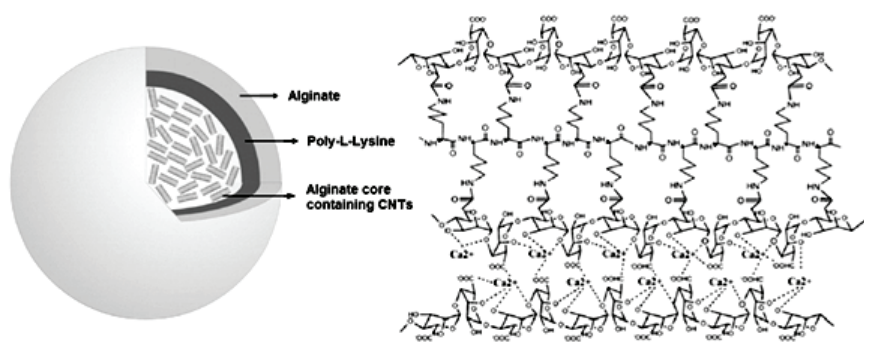

Figure 7. Alginate-poly-L-lysine-alginate microcapsules encapsulating carbon nanotubes (CNTs); the calcium ions are responsible for cross-linking of the alginate monomeric units trapping the carbon nanotubes into the core of microcapsule [84]

Encapsulated proteins from the alginate matrix can be released in two ways. The first is a mechanism for the diffusion of proteins through polymer networks. The second mechanism is the degradation of polymer network. The degradation of gel networks is not a suitable way for the controlled release of protein drugs, because it could result in a quick release of proteins. Therefore, it is better when the matrix remains intact and the drug diffuses out through the pores, which is a more suitable approach for the proteins delivery. The pore size of micro grain alginate is between 5 and $200 \mathrm{~nm}$, and the surface pores of the grain narrower than the pores in the core [40]. Unlike smaller chemical drugs, the diffusion of larger proteins from the gel (fibrin, insulin) depends on their molecular mass [41].

Protein charge can also affect the speed of their diffusion from the alginate matrix. A capsulated protein with a positive electric charge interacts with a negatively charged alginate, which inhibits its diffusion from the gel [29], whereas a negatively charged protein can be released from the matrix significantly more quickly. Therefore, the electric charge of the captured protein drug is a crucial factor for the efficiency of the controlled release of a drug from the alginate matrix. Porosity is another important factor for the release of the drug from alginates, and it can be significantly decreased by means of partly drying the pearls [42]. Complete dehydration can cause the surface to crack, which makes surface erosion of the pearls through rehydration easier. These phenomena limit the efficacy of the alginate matrix for the protein release. Low $\mathrm{pH}$ causes the pores of the alginate grain to shrink, significantly decreasing the release of macromolecules from the gel, which is an advantage in oral application. In addition, the percentage of $\alpha$-L-guluronic acid also influences the speed of the protein release. Alginates with a lower content of guluronic acid and lower molecule mass release the encapsulated proteins much more quickly [43].

Alginate beads/pearls as drug carriers

Ca-alginate pearls can be prepared in a simple way under mild gelation conditions. However, significant loss- es of the drug can occur during the preparation, in the event of leakage through the pores of the pearl. For the purpose of drug application, various modifications of alginate are suggested, one of which implies networking the alginate with aldehydes. As a result, sodium alginate on its own, or combined with ovalbumin or gelatin, networks successfully with aldehyde, while the microparticles and pearls are prepared for various applications [44]. Crosslinked alginate has a greater holding capacity of the captured drugs, and indicates a more controlled profile in the process of releasing drugs, for example sodium diclofenac (Fig. 8).

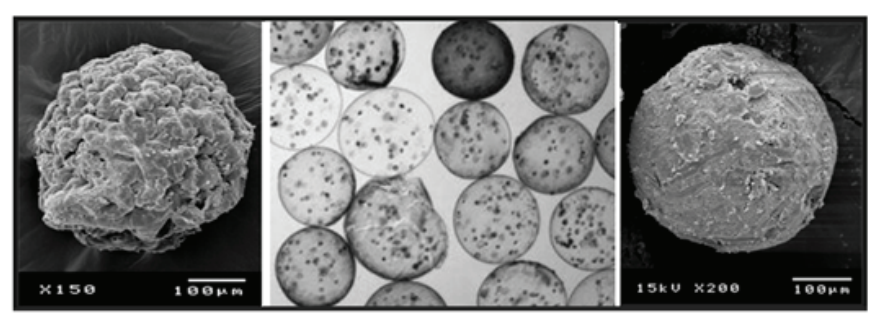

Figure 8. Scanning electron micrograph of diclofenac sodium alginate (scientific figure available from: https://www.researchgate.net/figure)

Table 1. Alginate-based matrices/scaffolds for drug and cell delivery described for different tissue engineering applications

\begin{tabular}{|c|c|c|c|}
\hline $\begin{array}{l}\text { Polymer(s)/carrier/ } \\
\text { scaffold structure }\end{array}$ & TE application & Active biomolecule & $\begin{array}{l}\text { Encapsulated/seeded } \\
\text { cell type (source) }\end{array}$ \\
\hline Alginate-chitosan fibers & Not defined & $\begin{array}{l}\text { Dexamethasone, } \\
\text { PDGF-BB }\end{array}$ & I \\
\hline Alginate hydroge| & Bone/cartilage & BMP-2 gene & $\begin{array}{l}\text { Bone marrow stromal } \\
\text { cells }\end{array}$ \\
\hline Alginate beads & Cartilage & BMP-2 & $\begin{array}{l}\text { Human articular } \\
\text { chondrocytes }\end{array}$ \\
\hline Alginate beads & Cartilage & rhOP-1 (medium) & $\begin{array}{l}\text { Bovine articular } \\
\text { chondrocytes }\end{array}$ \\
\hline $\begin{array}{l}\text { Alginate hydrogel } \\
\text { and film }\end{array}$ & Cartilage & $\begin{array}{l}\text { FGF-2 and TGF- } \beta \\
\text { (medium) }\end{array}$ & $\begin{array}{l}\text { Rabbit periostal } \\
\text { explants }\end{array}$ \\
\hline Alginate beads & Cartilage & BMP- $2,4,5,6,7$ & $\begin{array}{l}\text { Chondocytes } \\
\text { (transfected) }\end{array}$ \\
\hline Alginate hydrogel & Cartilage & $\begin{array}{l}\text { TGF- } \beta 1, \text { TGF- } \beta 2 \text {, } \\
\text { TGF- } \beta 13, \text { TGF- } \beta 4\end{array}$ & $\begin{array}{l}\text { Bovine synovim- } \\
\text { derived progen. cells }\end{array}$ \\
\hline Alginate beads & Cartilage & $\begin{array}{l}\text { Human platelet } \\
\text { supernatant }\end{array}$ & $\begin{array}{l}\text { Human articular } \\
\text { chondrocytes }\end{array}$ \\
\hline Alginate hydrogel & Vascularization & VEGF and bFGF & I \\
\hline $\begin{array}{l}\text { Alginate beads with } \\
\text { bioactive glass }\end{array}$ & Vascularization & $\begin{array}{l}\text { VEGF conditioned } \\
\text { medium }\end{array}$ & $\begin{array}{l}\text { Human CCD-18Co } \\
\text { fibroblast cells }\end{array}$ \\
\hline $\begin{array}{l}\text { Alginate gels in PP and PS } \\
\text { hollow-fibers }\end{array}$ & Vascularization & $\begin{array}{l}\text { Endothelial cell } \\
\text { growth supplement }\end{array}$ & 1 \\
\hline $\begin{array}{l}\text { Alginate hydrogels with } \\
\text { RGD }\end{array}$ & Bone & BMP-2 and TGF- $\beta 3$ & $\begin{array}{l}\text { Rat bone marrow } \\
\text { stromal cells }\end{array}$ \\
\hline Alginate hydrogel & $\begin{array}{l}\text { Intervertebral } \\
\text { disc }\end{array}$ & TGF- $\beta 1$ & $\begin{array}{l}\text { Human inervertebral } \\
\text { disc cells }\end{array}$ \\
\hline Alginate beads and disks & Cartilage & I & $\begin{array}{l}\text { Human adipose- } \\
\text { derived stem cells }\end{array}$ \\
\hline Alginate hydrogel & Cartilage & Glucose (medium) & $\begin{array}{l}\text { Cattlle articular } \\
\text { chondrocytes }\end{array}$ \\
\hline $\begin{array}{l}\text { Alginate hydrogel } \\
\text { in Ethisorb210 }\end{array}$ & Cartilage & 1 & $\begin{array}{l}\text { Bovine articular } \\
\text { chondrocytes }\end{array}$ \\
\hline Alginate hydrogel & Cartilage & I & $\begin{array}{l}\text { Bovine articular } \\
\text { chondrocytes }\end{array}$ \\
\hline $\begin{array}{l}\text { Alginate gel alone and } \\
\text { in PGA-PLA pads }\end{array}$ & Cartilage & I & $\begin{array}{l}\text { Rabbit rib chondro- } \\
\text { progenitor cells }\end{array}$ \\
\hline $\begin{array}{l}\text { Oxidized alginate } \\
\text { injectable hydrogel }\end{array}$ & Liver & I & Rat hepatocytes \\
\hline Alginate beads & Pancreas & I & $\begin{array}{l}\text { Murine insulinoma } \\
\text { BTC } 3 \text { cells }\end{array}$ \\
\hline
\end{tabular}

Abbreviations PDGF-BB: recombinant human platelet-derived growth factor-BB; BMP: bone morphoge-
netic protein; IGF-1: insulin growth factor; TGF- $\beta$ : transforming growth factor; FGF: fibroblast growth factor; rhOP-1: recombinant human osteogenic protein-1; EGF; epidermal growth factor; VEGF: vascular endothelial growth factor; BDNF: brain derived neutrophic factor; CCD 18Co: normal colon fibroblast cells derived from human colon; HDMECA: adult human dermal microvascular endothelial cells; PGA-PLA: co-polymer of polyglycolic acid-polylactic acid Ethisorb210: non-woven fleece composed of a polyglycolic-polylactic-copolymer punctually glued with polydioxanon; PP: polypropylene, PS: polysulfone. 
Many different methods for the preparation of alginate pearls have been developed, which can help in overcoming the problems of relatively large pores and physical instability of alginates at higher $\mathrm{pH}$ of the medium. Moreover, many of the modifications provide alginate hydrogels with additional improved functions responsible for a more efficient delivery of proteins. The most significant ones include the covalent chemical modification (thiolated alginate, hydrophobically modified alginate) and the production of polyelectrolyte complexes (alginatechitosan complexes, complexes with other polycations) [20]. Due to their biocharacteristics and mild conditions of the gelation process, alginates as natural polymers are widely applicable in tissue engineering, as shown in Table 1, which also examines the factors of the drug delivery or cell encapsulation [45].

\section{Alginate microparticles/microcapsules}

As mentioned above, in order to be used in biomedicine, certain improvements in physical, chemical and mechanical properties of alginate hydrogel must be made [46]. Instead of ionically networked hydrogels, covalently networked alginate hydrogels are used for that purpose, produced by mixing alginates with appropriate biocompatible and biodegradable polymers of natural or synthetic origin which possess chains much more flexible than the stiff polysaccharide chains such as alginate. Calcium alginate poly-(L-lysine) microcapsules are frequently used in biomedicine (Fig. 7). These microcapsules are produced by coating the ionically networked Ca-alginate microparticles with a layer of poly-(L-lysine) and forming an elastic membrane on the surface of the alginate hydrogel particle. Depending on the duration of the contact between the alginate hydrogel with the poly(L-lysine) solution, it is possible to get membranes with different properties (i.e. various permeability). Microcapsules prepared in this manner can be treated with the $\mathrm{Na}$-citrate which diffuses through the membrane and partially dissolves the alginate hydrogel structure within the microcapsule. The resulting polyelectrolitic solution of $\mathrm{Na}$-alginate inside the microcapsule represents the more optimal environment (e.g. for the biomass growth) [47]. The development of such microsystems and nanodesigned particles opens up new paths in the development of intelligent bioderivative materials and hydrogels, as well as the development of nanomedical techniques and biomedical engineering [47].

For their use in biomedicine, especially in tissue engineering, it is crucial to provide a strict control of the properties of biomaterials, particularly the speed of degradation and biomechanical characteristics [48]. Ionically networked alginates dissolve at the $\mathrm{pH}$-neutral value in the presence of citrates, phosphates, lactates, as well as in the presence of $\mathrm{Na}^{+} \mathrm{i} \mathrm{Mg}^{2+}$ cations. In the process, they lose the divalent bonding cations, which results in uncontrolled and slow degradation in vivo [49]. This causes the hydrogels to swell at first, which is followed by the destruction of the structure.

\section{Swelling}

The research of the swelling in calcium-alginate hydrogels has shown that the kinetics and degree of swelling depend on the concentration and content of alginates [50], especially the fraction (share) of G blocks [51], the concentration of $\mathrm{Ca}^{2+}$ ions in the solution used for gelation, the concentration of anti-gelation agents [52], and the $\mathrm{pH}$ value of the solution in which the swelling takes place [53]. Generally speaking, higher alginate concentrations with a higher share of $\mathrm{G}$ blocks and a higher content of $\mathrm{Ca}^{2+}$ ions during gelation result in the formation of firmer structures less prone to swelling. Dried hydrogels swell in water solutions due to hydration of polymer chains, while the degree of swelling increases with the $\mathrm{pH}$ value increase. The presence of $\mathrm{Na}^{+}$ions results in the increased degree of swelling and water absorption, as a consequence of the exchange of $\mathrm{Ca}^{+}$ions, mostly bonded with mannuron residues, which brings about the increase of electrostatic repulsion of carbon groups and relaxation of the polymer chains [52]. Moreover, the presence of citrate, phosphate and lactate ions stimulates ionic exchange and dissolution of calcium-alginate hydrogels, due to greater affinity towards the $\mathrm{Ca}^{2+}$ ions and the creation of insoluble calcium salts [54].

Figure 9 illustrates alginate microparticles from the three experimental series after spending (aging for) 10 days in solutions $(0.5 \mathrm{mM}, 0.2 \mathrm{mM}$ i $0.05 \mathrm{mM})$ of $\mathrm{Na}-$ citrate [55]. The microparticles from experimental series 1 have mostly degraded, leaving behind a significant amount of undissolved pieces of particles in the solution, while some particles which still remained whole had a very cracked surface with undissolved pieces detaching themselves from it (Fig. 9a). On the other hand, the microparticles from experimental series 2 mostly remained intact, although some particles with a cracked and wrinkled surface are noticeable, as well as the other, apparently intact ones (Fig. 9b). Finally, the microparticles form experimental series 3 do not differ in appearance from the control microparticles: spherical, transparent and smooth (Fig. 9c).
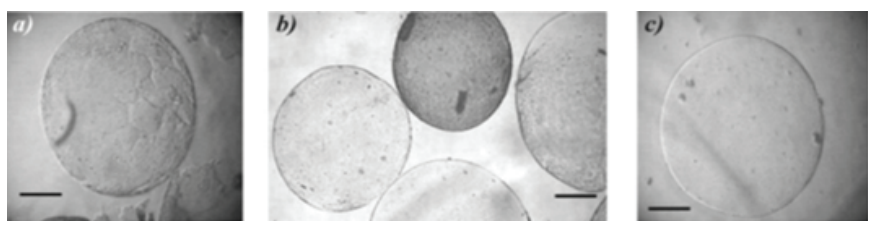

Figure 9. Alginate microparticles after spending 10 days in Nacitrate solutions: a) $0.5 \mathrm{mM}$ - cracked particle surface and the remains of degraded particles; b) $0.2 \mathrm{mM}$ - particles with wrinkled or cracked surface; c) $0.05 \mathrm{mM}$-smooth particle surface with no signs of degradation [55]

Specific swelling speeds represent the speed at which polymer chains straighten mostly due to the exchange of calcium ions bonded to the mannuron residues. In different experimental conditions, e.g. at higher concentrations of anti-gelation ions, a simultaneous 
exchange of calcium ions bonded to the guluronic residues can occur, leading to higher swelling speeds. In this manner, a previous research on swelling and degrading of dried alginate particles dipped into phosphate buffers (10 - $100 \mathrm{mM})$ has shown a significantly higher swelling speed. These remarks point out that the process of swelling depends on the specific gel structure in the individual particles and that the release of calcium ions is not uniform, but it is performed from individual segments. These segments are arranged differently in different particles, which is also in line with the proposed mechanism.

\section{Degradation}

Alginate hydrogels represent attractive biomaterial to be applied in pharmacy and medicine, either as filler at injured spots, or a carrier of therapeutic substances and cells in regenerative medicine and tissue engineering. Thereby, the microparticles are particularly suitable as a type of carrier because they allow a small diffusion distance, and simple implantation without the need for surgical procedure. In the potential application of alginate microparticles in medicine, two important factors stand out: the possibility of controlled degradation and biomechanical characteristics of the alginate gel, as well as the packed layer of particles. The examinations have been made concerning the possibility of controlled degradation of alginate microparticles in solutions of cultivating mediums for mammal cells, enriched with small concentrations of sodium citrate. In studies that have lasted up to 5 weeks it was shown that alginate microparticles, in this cultivation medium, without the addition of citrate ions, remained stable and nearly constant at diameter. When adding sodium citrate in the examined concentration range (from 0.05 to $0.5 \mathrm{mM}$ ), it was noted that first swelling of the particles occured, followed by a period of stability and finally degradation. These results are in agreement with the degradation mechanism of calcium alginate hydrogel published in literature [52], according to which sodium ions first replace the calcium ions bonded to the remains of mannuronic acid, which results in the gel swelling. Modeling the absorbed amount of water depending on time in this paper showed that the swelling process of alginate microparticles is limited by the speed of straightening of polymer chains in the process of exchange of calcium and sodium ions, which is in accordance with the results of the research on the swelling of alginate particles over $1 \mathrm{~mm}$ in diameter and with alginate concentration from 2.5 to $4 \% \mathrm{w} / \mathrm{v}$.

\section{Alginates in biomedicine}

Alginate, a natural polymer, is of high interest for industrial and biomedical application. For example, in the field of pharmacy, alginate in the form of gel is used as an excipient in tablets, for the purpose of the controlled release of a drug [56]. Due to the characteristics of calcium alginate gel (biocompatibility, mucoadhesivity, porousness, the possibility of manipulation), nowadays a lot of attention is directed to delivering the protein within the organism, cell encapsulation and tissue regeneration. Considering the delivery of the medicine/protein, many studies suggest various areas of application for calcium alginate gel pearls or microspheres. For that purpose, the surface of the alginate gel matrix is modified by macromolecules which are able to establish ionic interactions with alginate carboxylate ions, forming a layer around the alginate gel which then becomes resistant and suitable for various applications (Fig. 10).
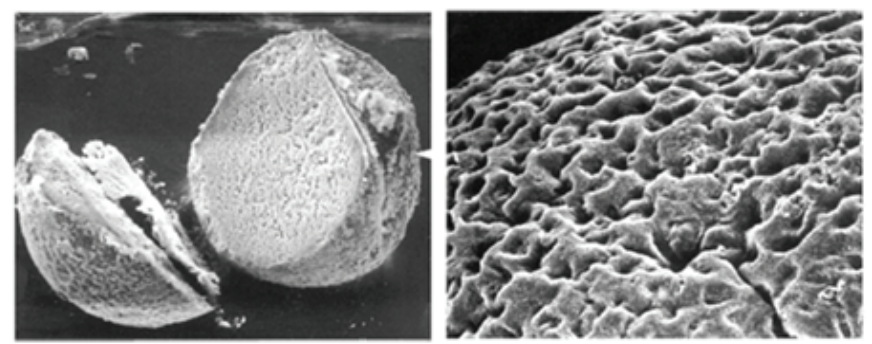

Figure 10. Scanning electron micrographs of Ca-alginate microspheres; cross-section and surface detail [85]

As typical surface modifying agents, chitosan, its derivatives and poly-L-lysine are used [3]. Another method of surface modification of the calcium alginate matrix and microsphere is forming a chemical crosslinked layer around the alginate core. For example, pearls/beads with a multilayered coat of chitosan crosslinked with tripolyphosphate are able to modify the release of amoxicillin in the in vitro experiments, and show improved mechanical resistance of pearls/beads [57]. Genipin, a natural networker for chitosan, is used for the preparation of alginate-chitosan pearls [58]. The obtained systems, encapsulated by indomethacin or bovine serum albumin, as a model of a protein drug, display the adjustable release dependent on the specific applied procedures and on the $\mathrm{pH}$ medium.

The approach based on the technique of calcium alginate gel microspheres coating is used for the preparation of microcapsules. In particular, when the outer layer is composed of multilayer poly(allylamine hydrochloride)/ poly(styrene sulfonate), as is the case with the microcapsules, it displays unusual behavior i.e. the attraction of positively charged macromolecules within the structure. This is potentially a very promising technique of delivery of macromolecular drugs in biomedical and biotechnological applications [59].

Due to their gelation properties, the use of alginates is also suggested in the field of pharmacy, for the delivery of drugs in ophthalmological conditions, considering the fact that this form of dosing is more efficient than commercial eye solutions. For example, a better prolonged drug delivery such as policarpine [60] and carteolol [61] was obtained, compared to the same drugs applied in the form of a solution.

The forming of the alginate gel has also been used for the examination of oral drug application. In particular, for the release of paracetamol or cimetidine from the oral formulation of alginate water solution, the system of the 
drug and calcium-citrate complex was examined. Once the solution is swallowed, the acidity of the stomach allows the calcium ions to interact with alginate, which leads to gel formation [62].

Based on the mixture of methyl cellulose and alginate, new systems for the delivery of drugs have been obtained which depend on the $\mathrm{pH}$ and temperature. At room temperature, the polymer solution can be easily combined and filled with drug, but the system obtained is converting into a gel with increasing the temperature after entering the human body, due to the termogelling properties of methyl cellulose. Acidic alginate gel is formed when the solution is in contact with the medium at low $\mathrm{pH}$ values. Thus, in simulated gastric fluid for example, this kind of a system is able to release bovine serum albumin more slowly in comparison to the neutral environment or in simulated intestinal fluid [63].

Gel can also be formed in the process of hiding calcium ions in thermo sensitive liposomes. When stored at $20^{\circ} \mathrm{C}$, the calcium liposome/alginate mixture remains liquid, while gelation occurs when the system is heated above the liposome phase crossover temperature, due to the loss of trapped calcium. Although the lack of stability of the liposome limits the storing conditions, the use of such a system is not excluded, since two components can also be mixed just before the injection [64].

Because of its properties, the alginate gel has also found its use in bandaging wounds, bearing in mind the presence of calcium ions in exudate [65]. The polymer matrix can capture antibiotics, such as vancomycin [66], or be mixed with other natural polymers, such as chitosan or gelatin. This gel network, resistant to collagenase digestion in vitroup to three days, can be filled with various drugs such as silver sulfadiazine or gentamicin sulfate, which are gradually released within a few days. This kind of system has also been tested positive in vivo.

One of more interesting areas pertaining to the application of the alginate gel, requiring further research, is the modulation of the delivery of drugs by mechanical and/or electric stimulation. For example, this is the way in which the influence of microwave radiation on the release of the drug from calcium alginate gel pearls, chitosan and calcium alginate mixtures was examined [67]. The effects vary depending on the differences in the stability of polysaccharides at different temperatures, as well as their different interactions and orders after radiation. Also, the capability of electric stimulation on the modulation of hydrocortisone release from the alginate gel which contains a larger amount of polyacrylic acid was examined [68].

A recent research refers to alginate mixtures with carbopol gel to obtain a semi-polymer interpenetrating networks (Semi-IPN) which were examined for electrical modulation of diclofenac release [69].

For the purpose of obtaining chemical or physical gels with characteristics different from the ones displayed when a natural polymer is used, various alginate derivatives were applied, apart from different polysac- charides. Alginate was chemically modified into low molar oligomers, which were then networked by biodegradable agents such as adipic dihydrazides until the biodegradable hydrogel was formed [70]. These kinds of systems, filled with antineoplastic agents (methotrexate, doxorubicin and mitoxantrone) display three different mechanisms of the release which occur simultaneously, and the improvement of the target drug is obtained by the decrease of side effects. Chemically stimulated hydrophobic modification (e.g. of alkyl chains by esterification of carboxylate groups) can change the behavior of alginates drastically, which resulted in a new type of the physical gel based on the hydrophobic interaction between the alkyl chains, intensified by calcium ions [71]. The release of drugs from these models of gel matrices showed extreme sensibility to the presence of tensides and enzymes that are able to break ester bonds.

Recent papers relate to the new composite materials based on alginate, gelatin and borax. These matrices are obtained by means of oxidation of alginate with periodate, which results in the forming of dialdehides capable of reacting with gelatin in the presence of borax. The matrix displays the hemostatic effect of gelatin, the function of alginate in wound healing and the antiseptic properties of borax, which makes it a potential woundhealing material [23].

Nowadays, most small and large drug molecules are inserted in the patient systematically (e.g. orally or intravenously) without using any particular carrier. In line with this, large doses are usually required for the desired spots with a specific effect due to the enzyme degradation of the drug and non-specific deduction from other tissues. This procedure is not only expensive, but can lead to serious side-effects. This is why the appropriate carrier provides a local and specific delivery of the drug to the desired tissue. A calcium alginate gel is especially suitable for this purpose. In particular, hydrogel formed in situ, filled with cisplatin and rhenium-188 was tested for regional radiochemotherapy of tumors [72]. Alginate networked by ethyleneglycol diglycidyl ether and calcium chloride, filled with mitomycin C (pharmacotherapeautical agent) is used in chemotherapy after transurethral resection; in vivo studies showed the plausibility of such a system [73].

Calcium alginate hydrogel can be used for tissue regeneration and as an encapsulation matrix for secretory cells. Even though this is already a well-examined area, there is an even bigger interest in the release of specific bioactive molecules and macromolecules. Regarding that, many studies relate to hydrogel systems which include proteins. One of the most important, most extensively researched proteins is the vascular endothelial growth factor (VEGF) which is embedded into the ionically networked alginate hydrogel [74] and which is delivered by diffusion and mechanical stimulation. The delivery of VEGF from alginate microspheres is larger due to the stabilization of the growth factor through the alginate interaction. The efficiency of this system on an- 
giogenesis around the implants was proven both in vitro and in vivo [75]. In addition, what was also examined was the release of the other angiogenic protein, the basic fibroblast growth factor (bFGF) from heparin-alginate hydrogel, and in this case the improvement in angiogenesis was recorded [76].

\section{Alginates in pharmacy}

Alginate treatment of heartburn

The use of alginate-based raft formulation has proven to be efficient in the treatment of heartburn and other symptoms related to the presence of the gastric content in the esophagus [77]. In vitro and clinical studies have shown that after taking the formulations in the form of tablets or liquid, alginate gel is formed due to the reaction of gastric acid with alginate and sodium bicarbonate. The forming of the raft depends to a great extent on whether the formulation includes bicarbonate which serves as a source of carbon-dioxide, providing buoyancy. The alginate raft serves as a barrier for acid and food, i.e. as a plug preventing the gastric content from going back into the esophagus. For example, gaviscon and other antireflux drugs containing alginate, similar to antacids, are able to significantly prolong the time of action up to 4 hours, compared to the 40 minutes for conventional antacids. Clinical research has proven the significant influence of these systems on the treatment of heartburn, and even the prevention of relapse.

\section{Alginate microparticles with antigen}

The use of alginate microspheres as oral or nasal systems for the application of antigen is very popular nowadays. Namely, polymer microspheres can protect the encapsulated antigens for acidic or proteolytic factors, and alginate itself possesses mucoadhesive properties which prolong the time of contact of the microsphere with the absorptive epithelium. Related to that, an evaluation of technological plausibility of inserting the antigen by alginate microspheres was performed [78]. Microspheres were prepared by the technique of emulsification and completely characterized as a system for the antigen delivery. The choice of the appropriate parameters enabled the application of alginate microspheres of $8 \mu \mathrm{m}$ average diameter. Bovine serum albumin (BSA) was chosen as the model of antigen. Encapsulation efficiency of the BSA model, as well as BSA, was very high $(90 \%$ and $10 \% \mathrm{w} / \mathrm{w}$ respectively). The encapsulation process does not affect the molecular mass or the antigenicity of the captured antigen. The release profile in vitro showed a high speed of release of the encapsulated BSA, especially in the saline solution of phosphate buffer. However, the decrease of the speed of release was noted when alginate microspheres were coated with poly(L-lysine) or prepared with alginate with a high molecular mass.

Immunization of mucosa by alginate microspheres

The immunization of mucosa is achieved with biocompatible and biodegradable alginate microspheres that contain conjugates of polysaccharide antigens and cholera toxin (CTB). For the purpose of preparing alginate microspheres with diameters less than $5 \mu \mathrm{m}$, a new diffusion-controlled gelation technique was developed. With a view to improving the immune response of mucosa, pneumococcal capsular polysaccharide type 19 (PS19) was conjugated With CTB (PS19-CTB). This conjugate was then encapsulated in the alginate microsphere. The content of PS19-CTB in the alginate microsphere is $60 \%$. In vitro studies showed that the microspheres release $80 \%$ of antigen in the course of one day [79].

\section{Alginate beads for controlled ampicillin release}

For controlled release of the antibiotic ampicillin, multi-layer beads based on alginate-chitosan with enhanced properties were developed [57]. The procedure of ionotropic gelation was applied for the preparation of simple and multi-layer beads (Figs.11-12). Different combinations of alginates and polyphosphates were used as anion components, and the combinations of chitosan and $\mathrm{Ca}^{2+}$ were used as cation components. The pearls were prepared at higher concentrations of chitosan, at which higher amounts of ampicillin are captured. During the incubation period, in simulated gastric fluid, the pearls grow larger and begin to float, though they show no signs of erosion. One-layer chitosan-alginate pearls release $70 \%$ of the drug within 4 hours, whereas multilayer beads release only $20-30 \%$ in the same period. During the additional incubation in a simulated intestinal fluid, both one-layer and multi-layer beads continue to release the drug due to the degradation of the pearls. The speed of drug release, both in gastric and intestinal fluids, as well as the kinetics of pearl degradation in the intestinal fluid can be controlled by means of changing the concentration of chitosan in the coagulated fluid. The release of the drug can also be controlled with crosslinking rate by the use of polyphosphates. Networked multi-layer beads were only prepared to release $40 \%$ of the captured drug in a 24-hour span. The conclusion was that chitosan-alginate multi-layer beads, networked by polyphosphate, offer the possibility for the controlled gastrointestinal passage of compounds with small molecular mass, such as ampicillin.

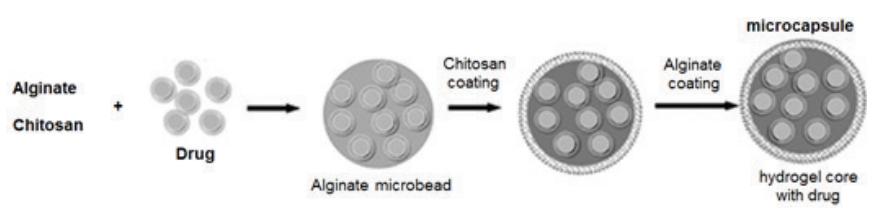

Figure 11. Encapsulation of drug by alginate-chitosan beads [86]
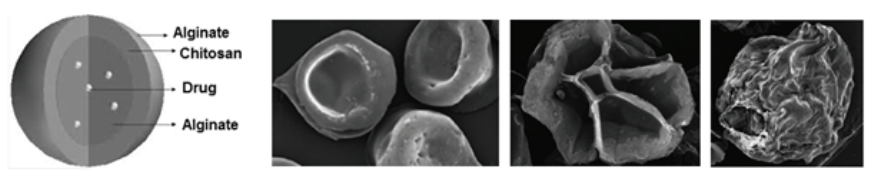

Figure 12. Model of multi-layer bead and SEM microphotographs of lyophilized alginate-chitosan beads with natural compounds [87] 
Alginate pearls for controlled diclofenac release

Sodium diclofenac causes side-effects in the organism such as ulcer bleeding or perforation of the intestinal wall. Considering the short biological half-life and side effects, sodium alginate-based pearls were developed as matrices for controlled release of sodium diclofenac [80]. The pearls were prepared by adding the sodium alginate solution with sodium diclofenac into methanol, followed by networking with glutaraldehyde (GA) in the acidic environment $(\mathrm{HCl})$. Various experimental conditions were tested (the percentage of networking, temperature), and the preparation of pearls was optimized according to the efficiency of capturing the drug, the swelling capacity of the pearls and the percentage of release. It was determined that the percentage of capturing efficiency varies in the range of 30 to 71 , depending on the conditions of the preparation. Pearls obtained at higher temperatures and longer periods of cross-linking demonstrated a lower efficiency of the capture, but extended the release of sodium diclofenac. The examinations by SEM method showed that the pearl surface is non-porous and smooth. The size of the pearls did not vary significantly, neither with the increase of exposure time to the crosslinking agent nor with the increase of the percentage of the active substance. However, the efficiency percentage related to the capturing of the drug varied with $\mathrm{pH}$, the temperature of the methanol solution and the period of disposal to the networking agent. Those pearls which were exposed to glutaraldehyde for a longer time demanded a longer time for drying. The data obtained from differential scanning calorimetry showed the dispersion of the drug in the pearl on the molecular level.

Alginate pearls, formulated by eudragit and chitosan, were examined on the example of controlled release of diclofenac salts i.e. hydroxyethyl pyrrolidine diclofenac [81]. In all the examined cases, a high efficiency of the drug capturing was achieved. By means of the destruction of the pearls, the examinations showed that eudragit-alginate pearls are hollow on the inside, whereas chitosan-alginate pearls have a dense, homogenous internal structure (Fig. 13). Moreover, the interaction between chitosan and the drug was also noted. In the conditions that imitate the gastric environment, it was noted that a small amount of the drug is being released. With alginate-chitosan pearls, it was proven that the release of the drug depends on $\mathrm{pH}$ value and the ratio of alginate-chitosan.

\section{Alginate microgel for ibuprofen release}

Pure ibuprofen is a non-steroid antiinflammatory drug extensively used in the treatment of various musculoskeletal conditions. Ibuprofen is easily absorbed through the gastro-intestinal tract, and is eliminated quickly after the application. Cellulose derivatives were used in the past as carriers of antihypertensive drugs. Sodium alginate as a biodegradable polymer can also be used for the controlled release of ibuprofen [82]. For the controlled release of ibuprofen and antiinflammatory drugs, microgel based on sodium alginate and acrylic acid was also developed [83]. Interpenetration nets of sodium alginate microgels and acrylic acids were prepared by using emulsion techniques water in oil (W/O). The influence of acrylic acid and the concentration of the drug on the speed of release of ibuprofen were also examined. The percentage of a cumulative release of ibuprofen from the microgel indicated that the matrix (sodium alginate - acrylic acid) is $\mathrm{pH}$ sensitive, which is ascribed to the diffusion of the drug through the surface of the microgel, which degrades after swelling, depending on the chemical content of the microgel and $\mathrm{pH}$ medium $(\mathrm{pH}$ 1.2 and 7.4 ). The alginate microgel network degrades in the intestinal fluid, while poly(acrylic acid) provides the $\mathrm{pH}$ sensitivity of the microgel network. It was determined that these interpenetrational microgel networks display a better encapsulation effect (83\%) and properties for forming simple units of dosage forms than regular sodium alginate microspheres $(50 \%)$. The microspheres have a lower density and can remain in the environment of the stomach for more than $12 \mathrm{~h}$, which improves the bioavailability of ibuprofen.
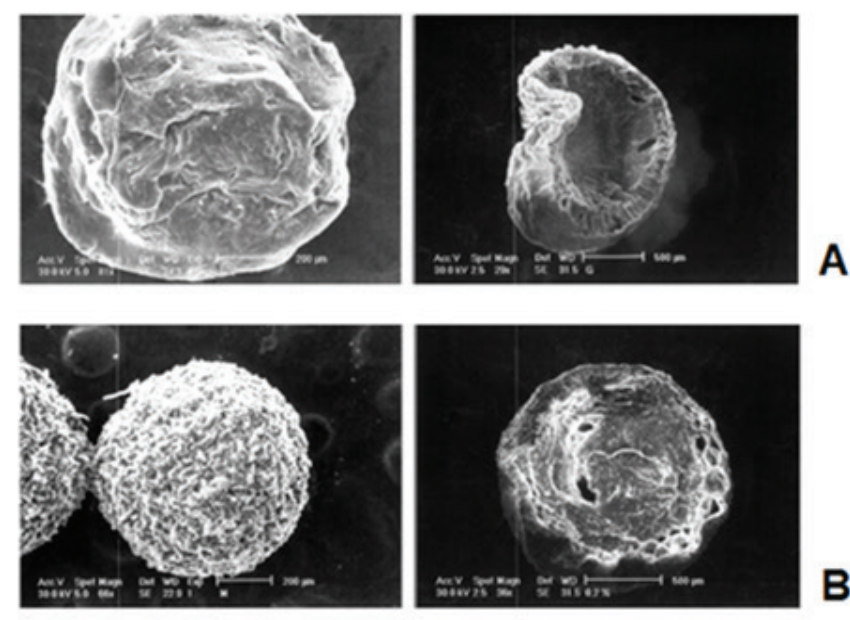

Figure 13. Micrographs of the external and internal structure of the pearls: A) eudragit-alginate; B) chitosan-alginate [81]

\section{Conclusion}

Unlike other polymers, polysaccharides and their derivatives show various and specific physical and chemical properties related to their complex structure, which is the reason for their very wide spectar of application, as shown in the paper. Biocompatibility, biodegradability, non-toxicity and hydrophility are properties that provide the possibility of their application, especially in pharmacy and biomedicine. Therefore, a large number of recent scientific publications refer to hydrogels obtained from natural and derivatized polysaccharides. These hydrogels in the form of microspheres or microcapsules are particularly important for the delivery of medical substances and microelements into the organism. A large number of researchers have paid special attention to the new types of alginate hydrogels which are responsible 
for the controlled release of drugs. Alginate is further adopted by $\mathrm{Ph}$. Eur. The review of properties and applications of these unique, $\mathrm{pH}$ sensitive, natural polysaccharide polymers offers a significant contribution to further research in this area.

\section{Acknowledgement}

This work was financially supported by the Ministry of Education, Science and Technological Development of the Republic of Serbia (research projects: TR 34012 and ON 172061).

\section{References}

[1] G.S. Nikolić, M.D. Cakić, Analysis of bioactive olygosaccharide-metal complexes by modern FTIR spectroscopy: copper complexes. Chapter 2, pp. 15-44. In book: "Fourier transforms - New analytical approaches and FTIR strategies", InTech., 2011.

[2] N. Peppas, P. Bures, W. Leobandung, H. Ichikawa, Hydrogels in pharmaceutical formulations, Eur. J. Pharm. Biopharm. 50 (2000) 27-46.

[3] T. Coviello, P. Matricardi, C. Marianecci, F. Alhaique, Polysaccharide hydrogels for modified release formulations, J. Control. Release 119 (2007) 5-24.

[4] M. Cakic, Z. Mitic, G.S. Nikolic, I. Savic, Design and optimization of drugs used to treat copper deficiency review, Drug Discov. 8(10) (2013) 1-11.

[5] M.D. Cakić, G.S. Nikolić, Iron complexes of pharmaceutical interest - Antianemics, Chem. Ind. 57(10) (2003) 437-443.

[6] M. Cakić, G.S. Nikolić, Lj. Ilić, FTIR spectra of iron(III) complex with dextran, pullulan and inulin oligomers, Bull. Chem. Technol. Maced. 21(2) (2002) 135-146.

[7] I. Savic, K. Nikolic, G.S. Nikolic, I. Savic, D. Agbaba, M. Cakic, Application of mathematical modeling for the development and optimization formulation with bioactive copper complex, Drug Develop. Ind. Pharm. 39(7) (2013) 1084-1090.

[8] G.S. Nikolić, M. Cakić, Lj. Ilić, S. Ristić, Ž. Cakić, Synthesis of some new antianemic: Iron pullulan complex of pharmaceutical interest, Pharmazie 57(3) (2002) 155158.

[9] Ž. Mitic, G.S. Nikolic, M. Cakic, P. Premovic, FTIR spectroscopic characterization of $\mathrm{Cu}(\mathrm{II})$ coordination compounds with exopolysaccharide pullulan and its derivatives, J. Molec. Struct. 924-926 (2009) 264-273.

[10] M. Cakić, Ž. Mitić, G.S. Nikolić, Lj. Ilić, G.M. Nikolić, The investigations of bioactive copper(II) complexes with reduced low molar dextran, Spectr. Int. J. 22(2-3) (2008) 177-185.

[11] Ž. Mitic, M. Cakić, G.S. Nikolić, Fourier-Transform IR spectroscopic investigations of cobalt(II)-dextran complexes by using D2O isotopic exchange, Spectr. Int. J. 4(3-4) (2010) 269-275.

[12] I. Savic, G.S. Nikolic, S. Zerajic, Gel filtration chromatography analysis and modeling the process of pullulan depolymerization, J. Polym. Eng. 32 (2012) 225233.

[13] G.S. Nikolić, M. Cakić, Physical investigations of colloidal iron-inulin complex, Colloid J. 69(4) (2007) 464-473.

[14] I. Savic, G.S. Nikolic, I. Savic, M. Cakic, Development and validation of gel-chromatographic and spectrophotometric methods for quantitative analysis of bioactive copper complexes in new antihypocupremical formulations, Acta Chromatogr. 22(3) (2010) 375-390.

[15] Lj. Ilić, S. Ristić, M. Cakić, G.S. Nikolić, S. Stanković Polynuclear $\mathrm{Fe}(\mathrm{III})$ complex with pullulan oligomers process of its obtaining, and pharmaceutical preparations on the basis of the complex, EP Pat. No. 1363951, 2003.

[16] W.E. Hennink, O. Franssen, W.N.E. Van Dijk-Wolthuis, H. Talsma, Dextran hydrogels for the controlled release of proteins, J. Control. Release 48(2-3) (1997) 107-114.

[17] X.Y. Wu, P.I. Lee, Preparation and characterization of inulin ester microspheres as drug carriers, J. Appl. Polym. Sci. 77(4) (2000) 833-840.

[18] V. Nikolić, M. Stanković, Lj. Nikolić, G. Nikolić, S. IlićStojanović, M. Popsavin, S. Zlatković, T. Kundaković, Inclusion complexes with cyclodextrin and usnic acid, J. Incl. Phenom. Macrocycl. Chem. 76 (2013) 173-182.

[19] A. Tačic, I. Savic, V. Nikolic, I. Savic, S. Ilic-Stojanovic, D. Ilic, S. Petrovic, M. Popsavin, A. Kapor, Inclusion complexes of sulfanilamide with $\beta$-cyclodextrin and 2-hydroxypropyl$\beta$-cyclodextrin, J. Incl. Phenom. Macrocycl. Chem. 80(12) (2014) 113-124.

[20] M. George, T. Abraham, Polyionic hydrocolloids for the intestinal delivery of protein drugs: alginate and chitosan review, J. Control. Release 114 (2006) 1-14.

[21] G. Skjak-Braek, H. Grasdalen, B. Larsen, Momomer sequence and acetylation pattern in some bacterial alginates, Carbohydr. Res, 154 (1986) 239-250.

[22] M. Stevens, H. Qanadilo, R. Langer, V. Prasad Shastri, A rapidcuring alginate gel system: utility in periosteumderived cartilage tissue engineering, Biomaterials 25 (2004) 887-894.

[23] B. Balakrishnan, M. Mohanty, P.R. Umashankar, A. Jayakrishnan, Evaluation of an in situ forming hydrogel wound dressing based on oxidized alginate and gelatin, Biomaterials 26 (2005) 6335-6342.

[24] S. Gulrez, S. Al-Assaf, G. Phillips, Hydrogels: methods of preparation, characterisation and applications. InTech. www.intechopen.com/books; 2011.

[25] S. Sugiura, T. Oda, Y. Izumida, Y. Aoyagi, M. Satake, A. Ochiai, N. Ohkohchi, M. Nakajima, Size control of calcium alginate beads containing living cells using micro-nozzle array, Biomaterials 26 (2005) 3327-3331.

[26] L.G. Griffith, Polymeric biomaterials, Acta Mater. 48 (2000) 263-277.

[27] K. Draget, G. Skjak-Braek, B. Stokke, Similarities and differences between alginic acid gels and ionically crosslinked alginate gels, Food Hydrocoll. 20 (2006) 170175.

[28] D.A. Rees, E.J. Welsh, Secondary and tertiary structure of polysaccharides in solution and gels, Angew. Chem. (Int. Ed. Engl.) 16 (1977) 214-224.

[29] T. Espevik, M. Otterlei, G. Skjak-Braek, L. Ryan, S.D. Wright, A. Sundan, The involvement of CD14 in stimulation of cytokine production by uronic acid polymers, Eur. J. Immunol. 23 (1993) 255-261.

[30] W.R. Gombotz, S.F. Wee, Protein release from alginate matrices, Adv. Drug Deliv. Rev. 31 (1998) 267-285.

[31] D.E. Chickering, E. Mathiowitz, Bioadhesive microspheres: A novel electrobalance-based method to study adhesive interactions between individual microspheres and intestinal mucosa, J. Control. Release 34 (1995) 251-261.

[32] H. Chang, H. Park, P. Kelly, J. Robinson, Bioadhesive polymers as platforms for oral controlled drug delivery. 
Synthesis and evaluation of some swelling, waterinsoluble bioadhesive polymers, J. Pharm. Sci. 74 (1985) 399-405.

[33] C.K. Kim, E.J. Lee, The controlled release of blue dextran from alginate beads, Int. J. Pharm. 79 (1992) 11-19.

[34] S. Chen, Y. Wu, F. Mi, Y. Lin, L. Yu, H. Sung, A novel $\mathrm{pH}$ sensitive hydrogel composed of $\mathrm{N}, \mathrm{O}$-carboxymethyl chitosan and alginate cross-linked by genipin for protein drug delivery, J. Control. Release 96 (2004) 285-300.

[35] N. Segi, T. Yotsuyanagi, K. Ikeda, Interaction of calciuminduced alginate gel beads with propanolol, Chem. Pharm. Bull. 37 (1989) 3092-3095.

[36] B.J. Lee, G.H. Min, Oral controlled release of melatonin using polymer rein forced and coated alginate beads, Int. J. Pharm. 144 (1996) 37-46.

[37] E.R. Edelman, A. Nathan, M. Katada, J. Gates, M.J. Karnovsky, Perivascular graft heparin delivery using biodegradable polymer wraps, Biomaterials 21 (2000) 2279-2286.

[38] M.R. Rasmussen, T. Snabe, L.H. Pedersen, Numerical modelling of insulin and amyloglucosidase release from swelling Ca-alginate beads, J. Control. Release 91 (2003) 395-405.

[39] B. Kim, T. Bowersock, P. Griebel, A. Kidane, L. Babiuk, M. Sanchez, S. Attah-Poku, R. Kaushik, G. Mutwiria, Mucosal immune responses following oral immunization with rotavirus antigens encapsulated in alginate microspheres, J. Control. Release 85 (2002) 191-202.

[40] A. Martinsen, G. Skjak-Braek, O. Smidsrod, F. Zanetti, S. Paoletti, Comparison of different methods for determination of molecular weight and molecular weight distribution of alginates, Carbohydr. Polym. 15 (1991) 171-193.

[41] H. Tanaka, M. Matsumara, I.A. Veliky, Diffusion characteristics of substrates in Ca-alginate gel beads, Biotechnol. Bioeng. 26 (1984) 53-58.

[42] O. Smidsrod, The relative extension of alginates having different chemical composition, Carbohydr. Res. 27 (1973) 107-118.

[43] Y. Murata, K. Nakada, E. Miyamoto, S. Kawashima, S.H Seo, Influence of erosion of calcium-induced alginate gel matrix on the release of Brilliant Blue, J. Control. Release 23 (1993) 21-26.

[44] A.R. Kulkarni, K.S. Soppimath, T.M. Aminabhavi, W.E. Rudzinski, In vitro release kinetics of cefadroxil-loaded sodium alginate interpenetrating network beads, Eur. J Pharm. Biopharm. 63 (2001) 97-105.

[45] P. Malafaya, G. Silva, R. Reis, Natural-origin polymers as carriers and scaffolds for biomolecules and cell delivery in tissue engineering applications, Adv. Drug Deliv. Rev. 59 (2007) 207-233.

[46] D.W. Green, I. Leveque, D. Walsh, D. Howard, X. Yang, K. Partridge, S. Mann, R. Oreffo, Biomineralized polysaccharide capsules for encapsulation, organization, and delivery of human cell types and growth factors, Adv. Funct. Mater. 15(6) (2005) 917-923.

[47] B. Bugarski, G. Jovanović, G. Vunjak-Novaković, Fundamentals of animals cells immobilization and microencapsulation. M.F.A. Goosen (ed.): CRC Pres, Boca Raton, 1993.

[48] A.D. Augst, H.J. Kong, D.J. Mooney, Alginate hydrogels as biomaterials, Macromol. Biosci. 6 (2006) 623-633.

[49] R. Forster, F. Thurmer, C. Wallrapp, A. Loyd, W. Macfarlane, G. Phillips, J. Boutrand, A. Lewis, Characterisation of physico-mechanical properties and degradation potential of calcium alginate beads for use in embolization, J. Mater. Sci: Mater. Med. 21(7) (2010) 2243-2251.

[50] P. Sriamornsak, R.A. Kennedy, Effect of a small molecule on diffusion and swelling properties of selected polysaccharide gel beads, Carbohydr. Polym. 79 (2010) 219-223.

[51] M. Davidovich-Pinhas, H. Bianco-Peled, A quantitative analysis of alginate swelling, Carbohydr. Polym. 79 (2010) 1020-1027.

[52] Y. Qin, Gel swelling properties of alginate fibers, J. Appl. Polymer. Sci. 91 (2004) 1641-1645.

[53] V. Pillay, R. Fassihi, In vitro release modulation from crosslinked pellets for site-specific drug delivery to the gastrointestinal tract: Comparison of $\mathrm{pH}$-responsive drug release and associated kinetics, J. Control. Release 59 (1999) 229-242.

[54] J. Zhang, Q. Wang, A. Wang, In situ generation of sodium alginate/ hydroxyapatite nanocomposite beads as drugcontrolled release matrices, Acta Biomater. 6 (2010) 445454.

[55] D. Mitrović, J. Stojkovska, B. Obradović, Controlled swelling and degradation studies of alginate microbeads in dilute natrium citrate solutions, Chem. Ind. 64(4) (2010) 253-263.

[56] M.M. Elnashar, M.A. Yassin, A.E. Moneim, E.M. Bary, Surprising performance of alginate beads for the release of low-molecular-weight drugs, J. Appl. Polym. Sci. 116 (2010) 3021-3026.

[57] A. Anal, W. Stevens, Chitosan-alginate multilayer beads for controlled release of ampicillin, Int. J. Pharm. 290 (2005) 45-54.

[58] F.L. Mi, H.W. Sung, S.S. Shyu, Drug release from chitosanalginate complex beads reinforced by a naturally occurring cross-linking agent, Carbohydr. Polym. 48 (2002) 61-72.

[59] R. Srivastava, M.J. McShane, Application of selfassembled ultra-thin film coatings to stabilize macromolecule encapsulation in alginate microspheres, $\mathrm{J}$. Microencapsul. 22 (2005) 397-411.

[60] S. Cohen, E. Lobel, A. Trevgoda, Y. Peled, A novel in situforming ophthalmic drug delivery system from alginates undergoing gelation in the eye, J. Control. Release 44 (1997) 201-208.

[61] O. Sechoyo, G. Tissie, C. Sebastian, F. Maurin, J.Y. Driot, C. Trinquand, A new long acting ophthalmic formulation of carteolol containing alginic acid, Int. J. Pharm. 207 (2000) 109-116.

[62] W. Kubo, S. Miyazaki, D. Attwood, Oral sustained delivery of paracetamol from in situ-gelling gellan and sodium alginate formulations, Int. J. Pharm. 258 (2003) 55-64.

[63] H. Liang, M. Hong, R. Ho, C. Chung, Y. Lin, C. Chen, $\mathrm{H}$. Sung, Novel method using a temperature-sensitive polymer (methyl cellulose) to thermally gel aqueous alginate as a pH-sensitive hydrogel, Biomacromolecules 5 (2004) 1917-1925.

[64] E. Westhaus, P.B. Messersmith, Triggered release of calcium from lipid vesicles: a bioinspired strategy for rapid gelation of polysaccharide and protein hydrogel, Biomaterials 22 (2001) 453-462.

[65] C. Valenta, B.G. Auner, The use of polymers for dermal and transdermal delivery, Eur. J. Pharm. Biopharm. 58 (2004) 279-289.

[66] S.S. Lin, S.W.N Ueng, S.S. Lee, E.C. Chan, K.T. Chen, C.Y. Yang, C.Y. Chen, Y.S. Chan, In vitro elution of 
antibiotic from antibioticimpregnated biodegradable calcium alginate wound dressing, J. Trauma 47 (1999) 136-141.

[67] T.W. Wong, L.W. Chan, S.B. Kho, P.W.S. Heng, Aging and microwave effects on alginate/chitosan matrices, J. Control. Release 104 (2005) 461-475.

[68] S.H. Yuk, S.H. Cho, H.B. Lee, Electric current-sensitive drug delivery systems using sodium alginate/polyacrylic composites, Pharm. Res. 9 (1992) 955-957.

[69] S.A. Agnihotri, R.V. Kulkarni, N.N. Mallikarjuna, P.V. Kulkarni, T.M. Aminabhavi, Electrically modulated transport of diclofenac salts through hydrogels of sodium alginate, carbopol, and their blend polymers, J. Appl. Polym. Sci. 96 (2005) 301-311.

[70] K.H. Bouhadir, E. Alsberg, D.J. Mooney, Hydrogels for combination delivery of antineoplastic agents, Biomaterials 22 (2001) 2625-2633.

[71] M. Leonard, M.R. De Boisseson, P. Hubert, F. Dalencon, E. Dellacherie, Hydrophobically modified alginate hydrogels as protein carriers withspecific controlled release properties, J. Control. Release 98 (2004) 395-405.

[72] A. Azhdarinia, D. Yang, D. Yu, R. Mendez, C. Oh, S. Kohanim, E. Kim, Regional radiochemotherapy using in situ hydrogel, Pharm. Res. 22 (2005) 776-783.

[73] M. Eroglu, E. Oeztuerk, N. Oezdemyr, E. Denkbap, I. Dogan, A. Acar, M. Guezel, Mitomycin-C-loaded alginate carriers for bladder cancer chemotherapy: in vivo studies, J. Bioact. Compat. Polym. 20 (2005) 197-208.

[74] J.L. Drury, D.L. Mooney, Hydrogels for tissue engineering: scaffold design variables and applications, Biomaterials 24 (2003) 4337-4351.

[75] K.Y. Lee, M.C. Peters, D.J. Mooney, Comparison of vascular endothelial growth factor and basic fibroblast growth factor on angiogenesis in SCID mice, J. Control. Release 87 (2003) 49-56.

[76] M. Tanihara, Y. Suzuki, E. Yamamoto, Y. Mizushima, Sustained release of basic fibroblast growth factor and angiogenesis in a novel covalently crosslinked gel of heparin and alginate, J. Biomed. Mater. Res. 56 (2001) 216-221.

[77] K.G. Mandel, B.P. Daggy, D.A. Brodie, H.I. Jacoby, Review article: Alginate-raft formulations in the treatment of heartburn and acid reflux, Aliment. Pharmacol. Ther. 14 (2000) 669-690.

[78] D. Lemoine, F. Wauters, S. Bouchend, V. Preat, Preparation and characterization of alginate microspheres containing a model antigen, Int. J. Pharmaceutics 176 (1998) 9-19.

[79] N. Cho, S. Seong, K. Chun, Y. Kim, I. Kwona, B. Ahnb, S. Jeong, Novel mucosal immunization with polysaccharideprotein conjugates entrapped in alginate microspheres, J. Control. Release 53 (1998) 215-224.

[80] A.R. Kulkarni, K.S. Soppimath, T.M. Aminabhavi, Controlled release of diclofenac sodium from sodium alginate beads crosslinked with glutaraldehyde, Pharm. Acta Helvet. 74 (1999) 29-36.

[81] M. Fernandez-Hervas, M. Holgado, A. Fini, J. Fell, In vitro evaluation of alginate beads of a diclofenac salt, Int. J. Pharmaceutics 163 (1998) 23-34.

[82] S.A. Agnihotri, N.N. Mallikarjuna, T.M. Aminabhavi, Recent advances on chitosan-based micro- and nanoparticles in drug delivery, J. Control. Release 100(1) (2004) 5-28.

[83] V. Ramesh-Babu, K. Krishna-Rao, M. Sairam, B. Vijaya Kumar Naidu, K.M. Hosamani, T.M. Aminabhavi, pH sensitive interpenetrating network microgels of sodium alginate-acrylic acid for the controlled release of ibuprofen, J. Appl. Polym. Sci. 99 (2006) 2671-2678.

[84] S. Prakash, M. Malhotra, W. Shao, C. TomaroDuchesneau, S. Abbasi, Polymeric nanohybrids and functionalized carbon nanotubes as drug delivery carriers for cancer therapy, Adv. Drug Deliv. Rev. 63(14-15) (2011) 1340-1351.

[85] G. Fundueanu, C. Nastruzzi, A. Carpov, J. Desbrieres, M. Rinaudo, Physico-chemical characterization of $\mathrm{Ca}$ alginate microparticles produced with different methods, Biomaterials 20 (1999) 1427-1435.

[86] L. Deladino, P. Anbinder, A. Navarro, M. Martino, Encapsulation of natural antioxidants extracted from llex paraguariensis, Carbohydr. Polym. 71 (2008) 126-134.

[87] A. Munin, F. Edwards-Levy, Encapsulation of natural polyphenolic compounds - A review, Pharmaceutics 3(4) (2011) 793-829. 


\section{ALGINATI I SLIČNI EGZOPOLISAHARIDI U BIOMEDICINI I FARMACIJI: KONTROLISANO OSLOBAĐANJE LEKOVA}

Dragana Marković ${ }^{1}$, Aleksandra Zarubica ${ }^{1}$, Nikola Stojković ${ }^{1}$, Marija Vasić1, Milorad Cakić2, Goran Nikolić2

\footnotetext{
1 Departman za hemiju, Prirodno-matematički fakultet, Niš, Srbija
}

2 Tehnološki fakultet, Univerzitet u Nišu, Leskovac, Srbija

Zbog velike dostupnosti, biokompatibilnosti, biodegradabilnosti, hidrofilnosti, kao i tehnoloških karakteristika, polisaharidi se široko koriste kao prirodni netoksični polimeri u različitim granama industrije (hrana, kozmetika, tekstil, građevinarstvo). U novije vreme, neki egzopolisaharidi (dekstran, pululan) su dobili značajnu ulogu u farmaceutskoj industriji. Od posebne važnosti su alginati, koji imaju nezamenljivu ulogu u biomedicini, obzirom da se u formi hidrogela uspešno primenjuju za imobilizaciju širokog spektra enzima, terapeutika, biohemijskih agenasa, kao i raznih vrsta mikroorganizama i ćelija (biljnih, životinjskih ili ljudskih). Alginatne mikrosfere se koriste za kontrolisano oslobađanje biološki aktivnih molekula, a mikrokapsule kao nosači ćelija u inženjeringu tkiva. Posebne pogodnosti proizilaze iz jednostavnosti konfiguracije alginatnog hidrogela, uključujući i mogućnost kontrolisane proizvodnje mikročestica i nanočestica. Uzimajući u obzir veoma važnu ulogu alginata u biomedicini i farmaciji, u ovom radu je posebna pažnja posvećena pripremi i primeni alginatnih matrica, mikrosfera i mikrokapsula, oblika koji mogu imati značajnu i nezamenljivu primenu. U tom smislu, ovaj rad pruža pregled različitih mogućnosti upotrebe polisaharidnih matrica za biomolekule, polisaharida kao ekscipijenasa farmaceutskih proizvoda za oralnu ili lokalnu primenu, kao i pregled primera inovativnih aplikacija.
(PREGLEDNI RAD)

UDK 577.114:615.01

Ključne reči: polisaharidi, alginati, mikrokapsule, biomedicina, farmacija. 